\title{
Early Onset of Reproductive Function in Female Rats Treated with a High-Fat Diet
}

\author{
Wirasak FUNGFUANG ${ }^{1,2) *}$, Nobuhiko NAKAO ${ }^{2)}$, Tomoaki NAKADA ${ }^{2)}$, Makoto YOKOSUKA ${ }^{2)}$ and Toru R. SAITO ${ }^{2)}$ \\ 1) Department of Zoology, Faculty of Science, Kasetsart University, Bangkok 10900, Thailand \\ ${ }^{2)}$ Laboratory of Behavioral Neuroscience, Nippon Veterinary and Life Science University, Japan
}

(Received 18 June 2012/Accepted 1 November 2012/Published online in J-STAGE 15 November 2012)

ABSTRACT. Puberty onset in mammals is tightly coupled to the animal's nutritional and metabolic state. In the present study, we evaluated the effects of a high-fat diet on leptin and adiponectin levels, leptin mRNA expression and puberty onset in female rats. On day 21 , female rats were divided into 2 groups, normal food (NF) and high-fat food (HF). The HF group showed a significantly earlier $(P<0.001)$ date of vaginal opening and lower body weight $(P<0.001)$ than the NF group. The rats fed the HF food had a significantly heavier uterus $(P<0.05)$ than those fed the NF food, whereas the serum leptin and adiponectin levels and leptin mRNA expression were not significantly different between the NF and HF groups. We speculate that the fat-induced nutritional imbalance in young females may lead to neuroendocrine dysfunction during adolescence.

KEY WORDS: adiponectin, female rats, high-fat diet, leptin, leptin mRNA.

doi: 10.1292/jvms.12-0276; J. Vet. Med. Sci. 75(4): 523-526, 2013

Puberty is a time of dramatic and sudden changes in energy balance as well as reproductive function, particularly in females. There is a marked increase in secretion of gonadotropin-releasing hormone and steroid hormones and also in preference for dietary fat and body fat accrual [11, 13]. The studies of Kennedy and Mitra [12] and Frisch et al. [10] established that the timing of sexual maturation is associated with body weight and composition. Studies suggest that increased nutrition before puberty as well as elevated weight gain and body fat may affect reproductive maturation and trigger the early onset of puberty [13]. The metabolic signals that could serve as molecular links between growth and reproduction remain to be determined.

Over the last few decades, a number of theories have been proposed with regards to the onset of puberty, factors suggested to cause onset of puberty range from "a critical weight" to "a critical level of metabolic signals" [12]. Nevertheless, none of these theories contain all the essential information, and it is likely that there is some truth in all of them. However, the metabolic signals that could serve as the links between growth and reproduction remained unknown. This may be the most important and contemporary issue in understanding puberty to determine how the brain knows when the body has reached the appropriate amount of the energy to begin high-frequency GnRH secretion [7, 8].

A positive relation between rate of sexual development in the rat and the amount of fat contained in the diet up to $20-40 \%$ has been reported, with high-fat diet rats having vaginal opening and estrous earlier than rats fed a low-fat diet, suggesting that a certain degree of fatness is the factor

*Correspondence to: Fungfuang, W., Department of Zoology, Faculty of Science, Kasetsart University, NgamWongwan Rd., Ladyaow, Chatuchak, Bangkok 10900, Thailand.

e-mail: fsciwsf@ku.ac.th

(C)2013 The Japanese Society of Veterinary Science controlling reproduction [9]. Adipose tissue serves as a longterm source of energy, and a critical amount of fat would be necessary for successful reproduction. There are some factors synthesized by adipose tissue that could be candidates for a signal to be detected by the brain [8].

The aim of the present study was to investigate the effects of a high-fat diet on serum leptin and adiponectin levels, leptin mRNA expression and puberty onset in weaning female rats treated with a high-fat diet.

Female 21-day-old Wistar-Imamichi rats were used in experiments 1 and 2 (Exp. 1 and Exp. 2). The animals were housed in individual cages, kept at $24 \pm 2{ }^{\circ} \mathrm{C}$ in a lightcontrolled room (12:12-hr light:dark cycle; lights on 07:00 to 19:00) and given free access to diet and water. All procedures were in accord with the National Institutes of Health, U.S.A., Guide for the Care and Use of Laboratory Animals and were approved by the Institutional Animal Care and Use Committee of the Nippon Veterinary and Life Science University.

On day 21, 12 females were divided into 2 groups in Exp. 1. One group was fed normal food (NF; Oriental MF, Oriental Yeast Co., Ltd., Tokyo, Japan), and the other was fed high-fat food (HF; 60\% fat, Oriental Yeast Co., Ltd., Tokyo, Japan). Body weight and food intake were measured at 08:00 hr. The vagina of each animal was inspected daily to determine the date of vaginal opening.

In Exp. 2, to measure serum leptin and adiponectin levels, all animals were sacrificed on day 26 between 14:00 and 15:00 hr, and trunk blood was collected and centrifuged at $2,200 \mathrm{~g}$ for $15 \mathrm{~min}$ at $4^{\circ} \mathrm{C}$. The serum was stored at below $-35^{\circ} \mathrm{C}$ until analyzed by ELISA for measurement of leptin and adiponectin levels (Morinaga Rat Leptin kit; Morinaga Institute of Biological Science, Inc., Yokohama, Japan). The ovaries, oviduct and uterus were dissected and weighed.

Total RNA was isolated using an RNeasy Lipid Tissue Midi Kit (Qiagen, Germantown, MD, U.S.A.) according to the manufacturer's instructions. RNA samples were 


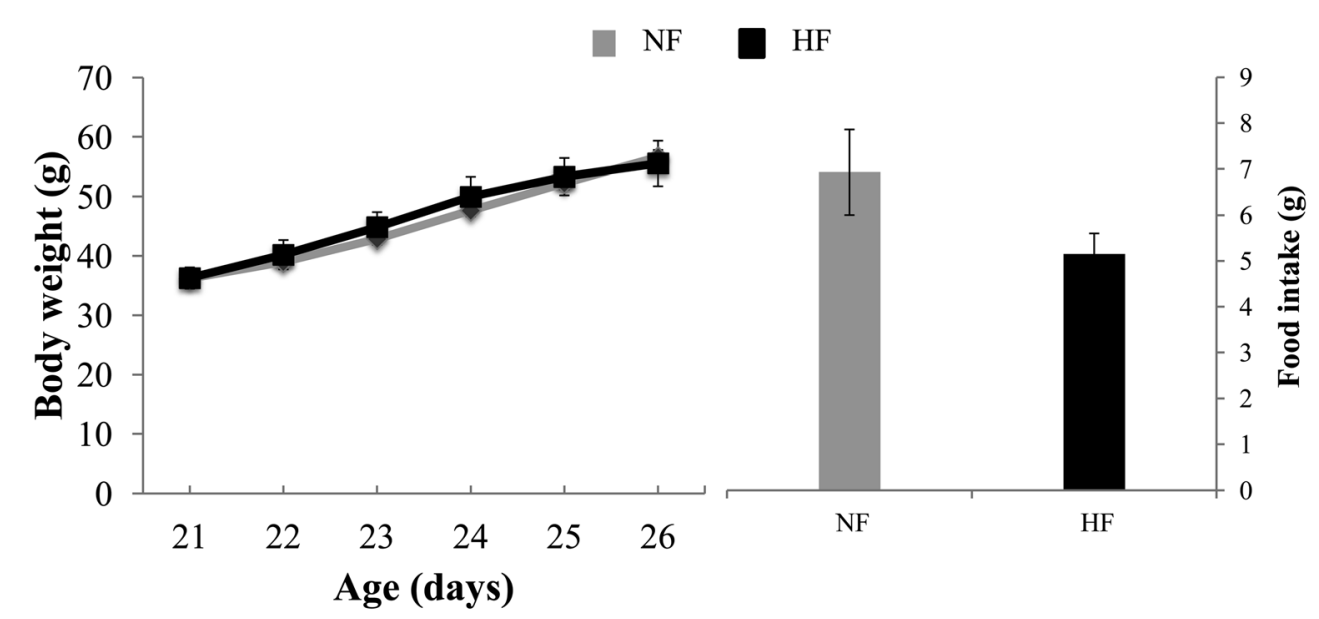

Fig. 1. Effects of HF on body weights and food intake.

quantified spectrophotometrically (NanoDrop, ND-1000, V3.12, Thermo Scientific, Wilmington, DE, U.S.A.), and the integrity was confirmed using $1.5 \%$ agarose gel. The total RNA was transcribed into first-strand cDNA for each sample using SuperScript ${ }^{\mathrm{TM}}$ III Reverse Transcriptase (Invitrogen, Carlsbad, CA, U.S.A.) in a final volume of $20 \mu l ; 1 \mu \mathrm{g}$ RNA sample was added with $1 \mu \mathrm{l}$ of $20 \mu \mathrm{M}$ oligodT Primer and DNase-free, RNase-free water. Samples were incubated at $65^{\circ} \mathrm{C}$ for $10 \mathrm{~min}$ and then placed on ice. A quantity of $4 \mu \mathrm{l}$ of $5 \mathrm{X}$ first-stand buffer, $2 \mu l$ of $0.1 \mathrm{M}$ DTT and $4 \mu l$ of 10 mMdNTP Mix were preincubating at $42^{\circ} \mathrm{C}$ for $2 \mathrm{~min}$, and then $0.5 \mu l$ of SuperScript ${ }^{\mathrm{TM}}$ III RT was added. Samples were incubated at $42^{\circ} \mathrm{C}$ for $1 \mathrm{hr}$ followed by addition of $30 \mu \mathrm{l}$ of TE and heating at $65^{\circ} \mathrm{C}$ for $10 \mathrm{~min}$ to inactivate the RTase.

Quantitative RT-PCR was performed using a specific forward primer (5'-GACCAGACCCTGGCAGTCTA-3') and reverse primer (5'-CTCAGCATTCAGGGCTAAGG-3') to amplify the product. Samples were normalized using the housekeeping gene, glyceraldehydes-3-phosphate dehydrogenase (GAPDH) with a forward primer (5'-TGTCAGCAATGCATCC TGCA-3') and reverse primer (5'-CCGTTCAGCTCTGGGA TGAC-3'). Real-time RT-PCR for the tested gene was performed in a $25 \mu l$ final reaction volume using Platinum SYBR Green qPCR SuperMix-UDG (Invitrogen, Carlsbad, CA, U.S.A.). Each real-time RT-PCR contained $12.5 \mu \mathrm{l}$ of Platinum SYBR Green qPCRSuperMixUDG, $10 \mu \mathrm{M}$ of each primer and RNA template. Real-time RT-PCR was carried out in duplicate for each sample in an ABI 7500 Real-Time RT-PCR System (Applied Biosystem, Foster City, CA, U.S.A.) using the following parameters: one cycle of $50^{\circ} \mathrm{C}$ for 2 min (UDG incubation) and then $95^{\circ} \mathrm{C}$ for $2 \mathrm{~min}$, followed by 40 cycles of $95^{\circ} \mathrm{C}$ for $15 \mathrm{sec}$ and $60^{\circ} \mathrm{C}$ for $30 \mathrm{sec}$. Melting curve analyses were run with each series to confirm the specificity of the amplified products. Amplifications were also performed without reverse transcriptase to confirm that there was no signal from the genomic DNA. Standard curves were prepared for both the tested and housekeeping gene. All expression data were normalized by dividing the amount of target gene by the amount of GAPDH used as control.

All data are expressed as the mean \pm SEM. Statistically significant differences were evaluated by ANOVA and Duncan's multiple range tests to examine the effects among subject variables. Differences were considered significant at $P<0.05$. The data for food intake and body weight are presented in Fig. 1. There were no significant differences in food intake and body weight between the rats fed the highfat and normal diets. The rats fed the high-fat diet consumed a smaller amount of food daily $(5.15 \pm 0.45 \mathrm{~g} /$ day $)$, corresponding to $73 \%$ of the amount consumed by the rat fed normal food $(6.96 \pm 0.94 \mathrm{~g} /$ day $)$.

The findings showed that the rats fed the high-fat diet showed precocious vaginal opening and had lower body weights on the day of vaginal opening (Table 1 and Fig. 2). By day 26, 3 of 6 rats fed the high-fat diet had already shown vaginal opening. In contrast, none of the 6 rats fed normal food showed vaginal opening by day 26 . The mean ages at vaginal opening in the rats fed the high-fat and normal foods were $27.67 \pm 1.12$ and $33.83 \pm 0.87$ days, respectively. There were significant differences between the two groups $(P<0.001)$. Interestingly, the HF group had a significantly lower body weight $(62.65 \pm 2.19)$ than the NF group on the day of vaginal opening. The HF group showed a significantly heavier weight of the uterus than the NF group. The weights of the ovaries and oviducts in the HF rats tended to be high compared with the NF group (Table 2).

Table 3 shows the serum leptin and adiponectin levels in prepubertal rats. The data showed that the serum leptin and adiponectin levels were not significantly different between the NF group and HF group. The data for leptin mRNA expression are shown in Fig. 3. The expression of leptin mRNA was not significantly different between the NF and HF groups $(0.0095 \pm 0.0011$ and $0.0094 \pm 0.0014$, respectively).

In this study, the authors evaluated the effects of a highfat diet on reproductive state, serum leptin and adiponectin levels and leptin mRNA expression in prepubertal female rats. The findings showed that rats fed the high-fat diet had an earlier age and lower body weight on the day of vaginal 


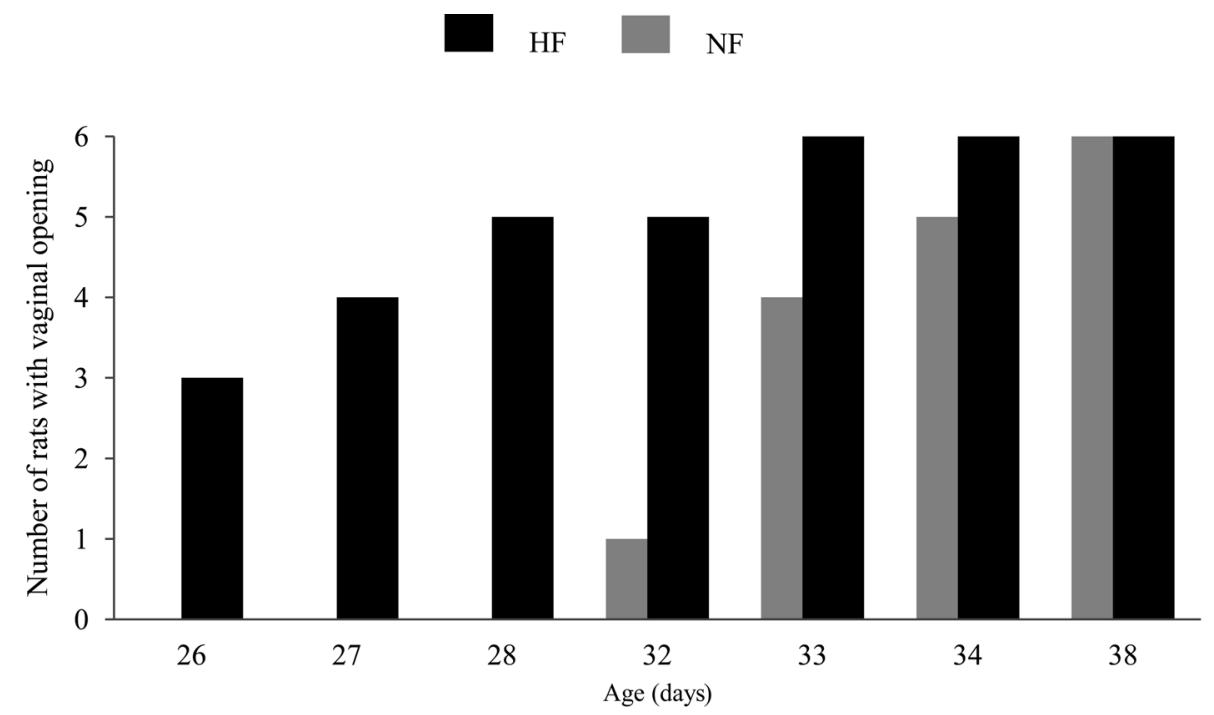

Fig. 2. Number of rats with vaginal opening in Wistar-Imamichi rats fed normal and high-fat foods.

Table 1. Puberty onset and body weights

\begin{tabular}{lcc}
\hline Feed & $\begin{array}{c}\text { Puberty onset } \\
\text { (days after birth) }\end{array}$ & $\begin{array}{c}\text { Body weight at } \\
\text { puberty onset }(\mathrm{g})\end{array}$ \\
\hline $\mathrm{NF}(\mathrm{n}=6)$ & $33.83 \pm 0.87$ & $95.23 \pm 3.09$ \\
$\mathrm{HF}(\mathrm{n}=6)$ & $27.67 \pm 1.12^{*}$ & $62.65 \pm 2.19^{*}$ \\
\hline
\end{tabular}

*Statistically significant by the Student's $t$-test $(P<0.001)$.

Table 2. Weights of the body and reproductive organs at day 26

\begin{tabular}{lcccc}
\hline Feed & Body $(\mathrm{g})$ & \multicolumn{1}{c}{ Uterus $(\mathrm{g})$} & Ovaries $(\mathrm{g})$ & Oviduct $(\mathrm{g})$ \\
\hline NF $(\mathrm{n}=6)$ & $56.60 \pm 1.13$ & $49.83 \pm 5.75$ & $15.72 \pm 1.12$ & $7.10 \pm 0.92$ \\
HF $(\mathrm{n}=6)$ & $55.18 \pm 1.87$ & $92.02 \pm 21.22 *$ & $16.36 \pm 1.14$ & $8.26 \pm 0.95$ \\
\hline
\end{tabular}

*Statistically significant by the Student's $t$-test $(P<0.05)$.

Table 3. Serum leptin and adiponectin levels in female rats on day 26

\begin{tabular}{lcc}
\hline Feed & Leptin $(n \mathrm{~g} / \mathrm{m} l)$ & Adiponectin $(\mu \mathrm{g} / \mathrm{m} l)$ \\
\hline $\mathrm{NF}(\mathrm{n}=6)$ & $0.80 \pm 0.08$ & $7.28 \pm 0.49$ \\
$\mathrm{HF}(\mathrm{n}=6)$ & $0.71 \pm 0.15$ & $6.40 \pm 0.33$ \\
\hline
\end{tabular}

opening compared with those fed the normal diet, which is in agreement with the previous findings on the effects of dietary fat on the age of sexual maturation in the rat [9]. These findings raise the possibility that an increase in the amount of calories from fat in the diet may have contributed to the secular trend to an earlier age of menarche and support the idea that a metabolic rate or energy balance signal is an initiating factor for puberty [12]. However, the metabolic signal that could serve as the links between growth and reproduction remains unknown. Although Kennedy's hypothesis still remains valuable, the critical weight is not the only factor affecting puberty onset [7, 8].

It is well known that the female reproductive processes

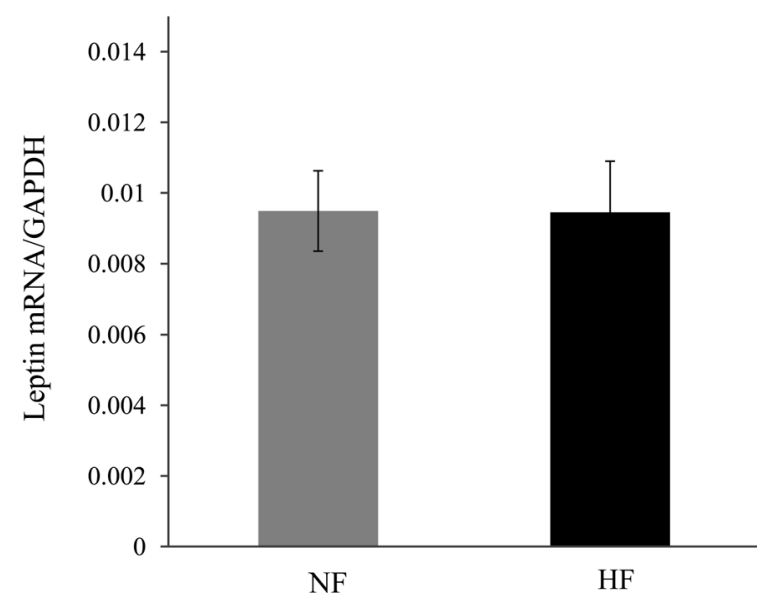

Fig. 3. Leptin mRNA expression in Wistar-Imamichi rats fed normal and high-fat foods.

are controlled by the change in metabolic fuel availability, suggesting that body fat distribution, rather than body fat weight, and appears to be early pubertal endocrine activity $[8,16]$. More recent research has shown that metabolic and nutritionally induced changes in reproductive function can occur without changes in body fat. A variety of hormones may act as possible signals of nutritional status for the reproductive system [15]. Leptin and adiponectin produced by adipose tissue may control the onset of reproductive function. Serum leptin levels are correlated with the degree of adiposity, and are regulated by feeding and fasting, whereas adiponectin levels are reduced in obese humans [5, 14] and rodents [17]. It was found that leptin treatment could advance reproductive maturation in both undernourished and well-fed animals [2-4].

Administration of recombinant leptin to female $o b / o b$ 
mice completely restores gonadotropin secretion, secondary sex organ weight and fertility $[1,2]$. Thus, comprehensive studies of any infertility or subfertility in a modified adiponectin model, which have yet to be conducted, are warranted given the alignment of physiological functions of adiponectin with leptin. Transgenic female mice expressing 2-3 times the normal circulating levels of adiponectin are infertile [6], although the extent and nature of this fertility defect have not yet been defined. Finally, our data showed that the weights of the uterus and oviducts in the HF group were higher than those in the NF group. We assessed that this finding may have resulted from high estrogen levels, which were not related to the leptin levels. In practice, serum $17 \beta$-estradiol levels $(<10 \mathrm{pg} / \mathrm{ml}$, below the level measurable by ELISA) were very low in the HF and NF groups (data not shown).

In conclusion, our findings suggest that leptin and adiponectin do not represent the primary signal that initiates the onset of puberty. Rather, leptin seems to be a permissive factor, acting as a metabolic gate or threshold to allow for sexual maturation, to proceed under adequate metabolic conditions. The authors speculate that fat-induced nutritional imbalance in young females may lead to neuroendocrine dysfunction during adolescence.

\section{REFERENCES}

1. Ahima, R. S. and Flier, J. S. 2000. Adipose tissue as an endocrine organ. Trends Endocrinol. Metab. 11: 327-332. [Medline] [CrossRef]

2. Barash, I. A., Cheung, C., Weigle, D., Ren, H., Kabigting, E., Kuijper, J., Clifton, D. and Steiner, R. 1996. Leptin is a metabolic signal to the reproductive system. Endocrinology 137: 3144-3147. [Medline] [CrossRef]

3. Caprio, M., Fabbrini, E., Isidori, A. M., Aversa, A. and Fabbri, A. 2001. Leptinin reproduction. Trends Endocrinol. Metab. 12: 65-72. [Medline] [CrossRef]

4. Chehab, F. F., Lin, M. E. and Lu, R. 1996. Correction of the sterility defect in homozygous obese female mice by treatment with the human recombinant leptin. Nat. Genet. 12: 318-320. [Medline] [CrossRef]

5. Cheung, C. C., Thornton, J. E., Kuijper, J. L., Weigle, D. S., Clifton, D. K. and Steiner, R. A. 1997. Leptin is a metabolic gate for the onset of puberty in the female rat. Endocrinology 138: 855-858. [Medline] [CrossRef]
6. Combs, T. P., Pajvani, U. B., Berg, A. H., Lin, V., Jelicks, L. A., Laplante, M., Nawrocki, A. R., Rajala, M. W., Parlow, A. F., Cheeseboro, L., Ding, Y. Y., Russell, R. G., Lindemann, D., Hartley, A., Baker, G. R., Obici, S., Deshaies, Y., Ludgate, M., Rossetti, L. and Scherer, P. E. 2004. A transgenic mouse with adeletion in the collagenous domain of adiponectin displays elevated circulating adiponectin and improved insulin sensitivity. Endocrinology 145: 367-383. [Medline] [CrossRef]

7. Cunningham, M. J., Clifton, D. K. and Steiner, R. A. 1999. Leptin's action on the reproductive axis:perspective and mechanisms. Biol. Reprod. 60: 216-222. [Medline] [CrossRef]

8. Foster, D. L. and Nagatani, S. 1999. Physiological perspective on leptin as a regulator of reproduction: role in timing puberty. Biol. Reprod. 60: 205-215. [Medline] [CrossRef]

9. Frisch, R. E., Hegsted, D. M. and Yoshinaga, K. 1975. Body weight and food intake at early estrous of rats on a high-fat diet. Proc. Natl. Acad. Sci. U.S.A. 72: 4172-4176. [CrossRef]

10. Frisch, R. E., Revelle, R. and Cook, S. 1973. Components of weight at menarche and the initiation of the adolescent growth spurt in girls:estimate total water, lean body weight and fat. Hum. Biol. 45: 469-483. [Medline]

11. Jean, C., Fromentin, G., Tome, D. and Larue-Achagiotis, C. 2002. Wistar rats allowed to self-select macronutrients from weaning to maturity choose a high-protein, high-lipid diet. Physiol. Behav. 76: 65-73. [Medline] [CrossRef]

12. Kennedy, G. C. and Mitra, J. 1963. Body weight and food intake as initiating factors for puberty in rat. J. Physiol. 166: 408-418. [Medline]

13. Leibowitz, S. F., Akabayashi, A., Alexander, J., Karatayev, O. and Chang, G. Q. 2009. Puberty onset in female rats:relation to fat intake, ovarian steroid and the peptide, Glanin and Enkephalin, in the paraventricular and medial preoptic nuclei. $J$. Neuroendocrinol. 21: 538-549. [Medline] [CrossRef]

14. Mitchell, M., Armstrong, D. T., Robker, R. L. and Norman, R. J. 2005. Adipokine: implications for female fertility and obesity. Reproduction 130: 583-597. [Medline] [CrossRef]

15. Pettigrew, J. E. and Tokach, M. D. 1991. Nutrition and female reproduction. Pig. News Info. 12: 559-562.

16. Schneider, J. E. 2004. Energy balance and reproduction. Physiol. Behav. 81: 289-317. [Medline] [CrossRef]

17. Yamauchi, T., Kamon, J., Waki, H., Terauchi, Y., Kubota, N., Hara, K., Mori, Y., Ide, T., Murakami, K., Tsuboyama-Kasaoka, N., Ezaki, O., Akanuma, Y., Gavrilova, O., Vinson, C., Reitman, M. L., Kagechika, H., Shudo, K., Yoda, M., Nakano, Y., Tobe, K., Nagai, R., Kimura, S., Tomita, M., Froguel, P. and Kadowaki, T. 2001. The fat-derived hormone adiponectin reverse insulin resistance associated with both lipoatrophy and obesity. Nat. Med. 7: 941-946. [Medline] [CrossRef] 